\title{
DESIGN OF DERMA STICKS OF ANDROGAPHIS PANICULATA FOR THE TREATMENT OF GYNAECOLOGICAL SKIN DISORDERS
}

\author{
SAVITA SONAWANE K. ${ }^{1}$, PURUSHOTHAM RAO ${ }^{2}$ \\ ${ }^{1}$ SVERIs College of Pharmacy, Gopalpur, M. S. India, ${ }^{2}$ H. K. Es College of Pharmacy, Gulburga, K. S. India \\ Email: savitasamu@gmail.com
}

Received: 20 Oct 2017, Revised and Accepted: 12 Dec 2017

\begin{abstract}
Objective: Vaginal candidiasis are often painful and uncomfortable and can include intense itching, irritation, vaginal discharge and dysuria. Gynaecological skin disorders referring to inflammatory and infectious conditions affecting the vaginal mucosa and vulvitis often accompanies vagina pain, itching and burning sensation. Herbal therapy is gaining popularity of women on account of its reduced side effect and restoration of the normal vaginal flora. Plants reported to possess activity or used in traditional systems of medicine for prevention and treatment of vaginitis. Therefore, it was found essential to find an alternative to counter all the above disadvantages effectively and hence in the present work, formulation and development of medicated sticks have been planned with the herbal drug Androgaphis Paniculata which is very well known for the antibacterial and antifungal activity.
\end{abstract}

Methods: The preparation and characterization of medicated sticks were carried out in four phases. Phase I studies include preparation of medicated derma sticks using the ointment bases with varied concentrations of waxes. Phase II studies involve characterization of prepared medicated derma sticks like weight, thickness and length. Phase III studies involves stability studies of prepared formulations. Phase IV Studies involves antimicrobial studies by zone inhibition method. .Phase V: Primary skin irritation studies carried out on rabbits and guinea pigs and in healthy human volunteers showed no sensitization and edema on the skin after $72 \mathrm{~h}$ of application.

Results: The results of present study revealed that the prepared medicated sticks of Androgaphis Paniculata are convenient, equally effective, without any contamination chances on the application and free from skin irritation.

Conclusion: The present work is a unique piece of contribution to the drug industry. The results will be useful to industry R\&D for further investigations. The continuation of these work clinical studies is in progress.

Keywords: Derma sticks, Androgaphis paniculata, Gynaecological skin disorders.

(C) 2018 The Authors. Published by Innovare Academic Sciences Pvt Ltd. This is an open access article under the CC BY license (http://creativecommons.org/licenses/by/4.0/) DOI: http://dx.doi.org/10.22159/ijcpr.2018v10i1.24400

\section{INTRODUCTION}

All ages of women are prone to suffer with many gynaecological disorders due to their poor living condition, poverty and maintain of poor hygienic atmosphere in normal healthy women, the vaginal cavity is inhabited by a number of microorganisms, existing in a dynamic microenvironment. Any disturbance to this ecosystem leads to a number of infectious conditions and disease [1-3].

Gynecological skin infections are very common in most of the woman population especially in rural areas due to unhygienic maintenance. Many patients express difficulty in application of ointments, creams, gels etc. results in non-compliance and ineffective therapy. A recent advance in novel drug delivery systems [NDDS] aims to enhance safety and efficacy of drug molecules by formulating a convenient dosage form for application and to achieve better patient compliance. One such approach is medicated sticks [4-5]. An advantage of this drug delivery system includes patient compliance; convenience and comfortness for efficient treatment include application without fingertip, immediate onset of action, reduced dosage regimen and economy [6-8]. Androgaphis Paniculata a herbal medication has antibacterial and antifungal activity commonly used in the treatment of several skin disorders as it is not available in such dosage form [910]. The objective of the present work was to develop such a NDDS of prepare Androgaphis Paniculata medicated derma sticks by heating and congealing method.

\section{MATERIALS AND METHODS}

Androgaphis Paniculata was gift sample from Euro drug Laboratory. Hyderabad., T. S. Stearyl alcohol pure, white petrolatum (Lobachemie Pvt. Ltd., Mumbai), Sodium lauryl sulphate, Cetyl Alcohol (SD fine chemicals ltd. Mumbai), Propylene glycol (Ranbaxy lab. Ltd., SAS Nagar), Methanol (Qualigens Fine Chemicals, Mumbai) were used.

Table 1: Formula of medicated derma stick

\begin{tabular}{lll}
\hline S. No. & Ingredients & Quantity in gms \\
\hline 1 & Androgaphis Paniculata powder & 1.00 \\
2 & Stearyl alcohol & 15.00 \\
3 & White petrolatum & 20.00 \\
4 & White Beeswax & 5.00 \\
5 & Sodium lauryl sulfate & 1.50 \\
6 & Propylene glycol & 12.50 \\
7 & Purified water (Q. S.) & 100.00 \\
\hline
\end{tabular}

Preparation of medicated derma sticks of androgaphis paniculata as drug

Medicated drumsticks were prepared by heating and congealing according to the formulae (table 1). Depending upon the weight, thickness and length of medicated derma sticks, the formulae was chosen for the incorporation of the drug. Stearyl alcohol [11] Cetyl alcohol [12] and white petroleum were melted in a china dish and heated this mixture up to $70{ }^{\circ} \mathrm{C}$. Dissolve sodium lauryl sulfate, propylene glycol in purified water and heat the solution to $70{ }^{\circ} \mathrm{C}$ 
separately. Add the oleaginous phase slowly to the aqueous phase, stirring constantly and then the Androgaphis Paniculata as the drug was added slowly with continuous stirring in order to get a uniform mixture in the optimized formulation. The hot mixture was poured into the glass mould and cooled to get the desired shape of sticks. The stick was removed from the mould after $24 \mathrm{~h}$ with the help of plunger and inserted into the medicated derma stick container (table 1).

\section{Evaluation of prepared medicated derma sticks}

Three sticks were selected randomly and weighed individually. The individual weights were compared with the average weight for determination of weight variation. As the shape of the stick is cylindrical the thickness and length were determined with the help of screw gauge and vernier callipers respectively. The average thickness was measured, by observing thickness at three different parts of the stick (table 2).

Table 2: Comparative data of weight, thickness and length of medicated derma sticks

\begin{tabular}{llll}
\hline Formulation code* $^{*}$ & Medicated stick & \\
\cline { 2 - 4 } & Weight (gm) & Thickness (mm) & Length (cm) \\
\hline AP & 4.62 & 6.35 & 3.9 \\
AP & 4.61 & 6.36 & 4.0 \\
AP & 4.63 & 6.37 & 4.1 \\
mean \pm SD & $4.62 \pm 0.01$ & $6.36 \pm 0.01$ & $4.0 \pm 0.01$ \\
\hline
\end{tabular}

*Each reading indicates mean of three replicate

Table 4: Zone of inhibition in diameter mm, no inhibition (--) DMSO-dimethyl sulfoxide as-ve control, +ve control for fungal Candida spsKetoconazole

\begin{tabular}{|c|c|c|c|c|c|c|}
\hline \multirow[t]{2}{*}{ Formulation code } & \multicolumn{3}{|c|}{ Statistical zone of inhibition (mm) after $36 \mathrm{~h}$} & \multirow[t]{2}{*}{ Mean \pm SD } & \multirow{2}{*}{$\begin{array}{l}\text {-Ve controle } \\
\text { (DMSO) }\end{array}$} & \multirow{2}{*}{$\begin{array}{l}+\mathrm{Ve} \\
\text { controle }\end{array}$} \\
\hline & Zone 1 & Zone 2 & Zone 3 & & & \\
\hline Pure Drug & 12 & 13 & 14 & $13 \pm 1.00$ & - & 35 \\
\hline AP (Plate-1) & 12 & 09 & 11 & $10.66 \pm 1.52$ & - & 35 \\
\hline AP (Plate-2) & 09 & 11 & 11 & $10.33 \pm 1.15$ & - & 35 \\
\hline AP (Plate-3) & 10 & 12 & 11 & $11.00 \pm 1.00$ & & 35 \\
\hline
\end{tabular}

\section{Antimicrobial studies of prepared formulations [13]}

The antimicrobial studies were carried out for the prepared formulations by a cup-plate method using Candida Albicans as the test organism. The cultures of Candida albicans were cultivated on Sabouraud's dextrose agar maintained on slants in the refrigerator $\left(4 \pm 2{ }^{\circ} \mathrm{C}\right)$ (table 4$)$.
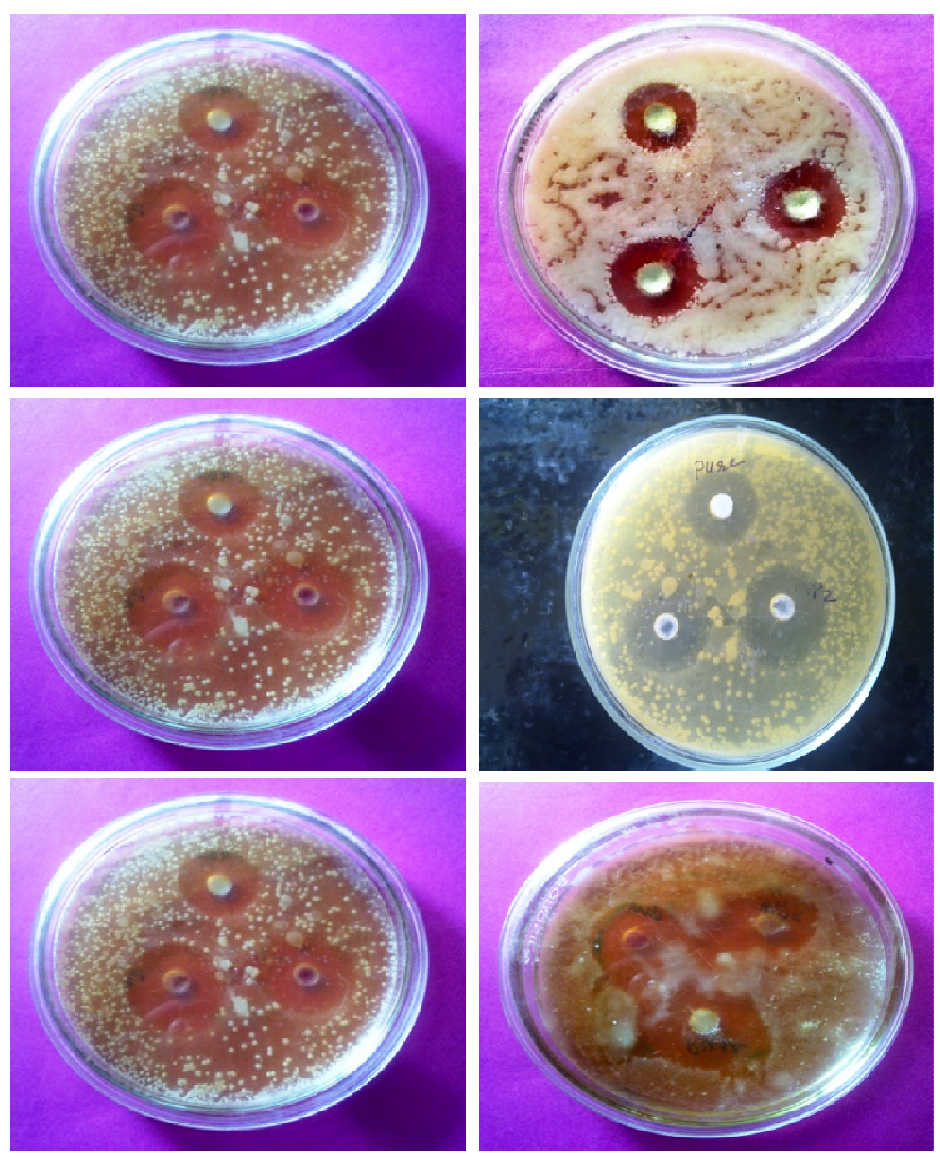

Fig. 1: Antimicrobial studies showing the comparative zone of inhibition of drug as pure and in the formulation 
Table 5: Skin irritation test data of prepared derma stick AP bases for rabbits

\begin{tabular}{|c|c|c|c|c|c|c|c|c|c|c|c|c|c|}
\hline \multirow[t]{2}{*}{ Formulation code } & \multirow[t]{2}{*}{ Rabbits } & \multicolumn{3}{|c|}{ Before application } & \multicolumn{3}{|c|}{ After $24 \mathrm{~h}$ of application } & \multicolumn{3}{|c|}{ After $48 \mathrm{~h}$ of application } & \multicolumn{3}{|c|}{ After $72 \mathrm{~h}$ of application } \\
\hline & & I & $\mathbf{R}$ & $\mathbf{E}$ & I & $\mathbf{R}$ & $\mathbf{E}$ & I & $\mathbf{R}$ & $\mathbf{E}$ & I & $\mathbf{R}$ & $\mathbf{E}$ \\
\hline \multirow[t]{3}{*}{$\mathrm{AP}$} & Female-I & $\mathrm{x}$ & $\mathrm{x}$ & $x$ & $\mathrm{x}$ & $x$ & $\mathrm{x}$ & $\mathrm{x}$ & $\mathrm{x}$ & $\mathrm{x}$ & $\mathrm{x}$ & $\mathrm{x}$ & $\mathrm{x}$ \\
\hline & Female-II & $\mathrm{x}$ & $\mathrm{x}$ & $\mathrm{x}$ & $\mathrm{x}$ & $\mathrm{x}$ & $\mathrm{x}$ & $\mathrm{x}$ & $\mathrm{x}$ & $\mathrm{x}$ & $\mathrm{x}$ & $\mathrm{x}$ & $\mathrm{x}$ \\
\hline & Female-III & $\mathrm{x}$ & $\mathrm{x}$ & $\mathrm{x}$ & $\mathrm{x}$ & $\mathrm{x}$ & $\mathrm{x}$ & $\mathrm{x}$ & $\mathrm{x}$ & $\mathrm{x}$ & $\mathrm{x}$ & $\mathrm{x}$ & $\mathrm{x}$ \\
\hline
\end{tabular}

I-Skin irritation, R-Redness, E-Erythema, AP-Andrographis paniculata

Table 6: Skin irritation test data of prepared derma stick AP bases for guinea pigs

\begin{tabular}{|c|c|c|c|c|c|c|c|c|c|c|c|c|c|}
\hline \multirow[t]{2}{*}{ Formulation code } & \multirow[t]{2}{*}{ Guinea pigs } & \multicolumn{3}{|c|}{ Before application } & \multicolumn{3}{|c|}{ After $24 \mathrm{~h}$ of application } & \multicolumn{3}{|c|}{ After $48 \mathrm{~h}$ of application } & \multicolumn{3}{|c|}{ After $72 \mathrm{~h}$ of application } \\
\hline & & I & $\mathbf{R}$ & $\mathbf{E}$ & $\mathbf{I}$ & $\mathbf{R}$ & $\mathbf{E}$ & I & $\mathbf{R}$ & $\mathbf{E}$ & I & $\mathbf{R}$ & $\mathbf{E}$ \\
\hline \multirow[t]{3}{*}{$\mathrm{AP}$} & Female-I & $\mathrm{x}$ & $\mathrm{x}$ & $\mathrm{x}$ & $\mathrm{x}$ & $\mathrm{x}$ & $\mathrm{x}$ & $\mathrm{x}$ & $\mathrm{x}$ & $\mathrm{X}$ & $\mathrm{x}$ & $\mathrm{x}$ & $\mathrm{x}$ \\
\hline & Female-II & $\mathrm{x}$ & $\mathrm{x}$ & $\mathrm{x}$ & $\mathrm{x}$ & $\mathrm{x}$ & $\mathrm{x}$ & $\mathrm{x}$ & $\mathrm{x}$ & $\mathrm{X}$ & $\mathrm{x}$ & $\mathrm{x}$ & $\mathrm{x}$ \\
\hline & Female-III & $\mathrm{x}$ & $\mathrm{x}$ & $\mathrm{x}$ & $\mathrm{x}$ & $\mathrm{x}$ & $\mathrm{x}$ & $\mathrm{x}$ & $\mathrm{x}$ & $\mathrm{X}$ & $\mathrm{x}$ & $\mathrm{x}$ & $\mathrm{x}$ \\
\hline
\end{tabular}

I-Skin irritation, R-Redness, E-Erythema, AP-Andrographis paniculata

\section{Cup-plate method}

Yeast peptone dextrose agar plate was prepared and $25 \mathrm{ml}$ of poured into sterile Petri dishes with species of candida albican. The depth of the medium was approximately $4 \mathrm{~mm}$. After the medium got solidified, the plates were allowed to dry for one hour. Wells in $6 \mathrm{~mm}$ diameter were punctured in the media using sterile cork borers. These wells in Petri dishes allowing a distance of 2 to $4 \mathrm{~cm}$ between each well and filled with $20 \mu \mathrm{l}$. The plates were then incubated at $37^{\circ} \mathrm{C}$ for $24 \mathrm{~h}$. Following incubation, bioactivity was determined by measuring the inhibition zones in $\mathrm{mm}$. All tests were done in triplicate. DMSO solvent is considered as negative control. Ketoconazole $(10 \mu \mathrm{l} / \mathrm{ml})$ was used as a standard antifungal drug (fig. 1).

\section{Preclinical studies: primary skin irritation test in animals [14]}

This test is conducted on 3 healthy rabbits and guinea pigs (three female), which were fed with fresh food and water during the test period. $24 \mathrm{~h}$ prior to test, the hair from the lower abdominal portion was shaved to expose sufficiently large test area. The test site was cleaned with surgical spirit then medicated stick is applied to test area. The test site was observed for erythematic and edema for $72 \mathrm{~h}$ after application. This test was conducted to evaluate the irritancy of the prepared medicated stick on the intact skin of rabbits and guinea pigs (table 5,6 ).

Preclinical studies: primary skin irritation test in healthy human being volunteers

Three Healthy Human Volunteers were selected for the study for each formulation. The test site was cleaned with surgical spirit then medicated stick is applied to test area. The test site was observed for erythema and edema for $24 \mathrm{~h} 48 \mathrm{~h}$ and $72 \mathrm{~h}$ after application. This test was conducted to evaluate the irritancy of the prepared medicated stick on the intact skin. None of the prepared medicated sticks showed any erythematic or edema, indicating that the prepared formulations were non-irritant on the skin. These studies were carried out under the guidance of qualified dermatologists with the permission of the ethical committee of M. R. Medical College, Gulbarga (table 7).

\section{Stability studies}

Short-term stability studies on the promising formulation MP-1 were carried out by storing the sticks at $27 \pm 2{ }^{\circ} \mathrm{C}$ for a period of three weeks. At intervals of one week, the sticks were visually examined for any physical changes (table 3).

Table 7: Skin irritation test data of prepared derma stick AP bases for healthy human volunteers

\begin{tabular}{|c|c|c|c|c|c|c|c|c|c|c|c|c|c|}
\hline \multirow[t]{2}{*}{$\begin{array}{l}\text { Formulation } \\
\text { code }\end{array}$} & \multirow[t]{2}{*}{$\begin{array}{l}\text { Human } \\
\text { volunteers }\end{array}$} & \multicolumn{3}{|c|}{$\begin{array}{l}\text { Before } \\
\text { application }\end{array}$} & \multicolumn{3}{|c|}{$\begin{array}{l}\text { After } 24 \mathrm{~h} \text { of } \\
\text { application }\end{array}$} & \multicolumn{3}{|c|}{$\begin{array}{l}\text { After } 48 \mathrm{~h} \text { of } \\
\text { application }\end{array}$} & \multicolumn{3}{|c|}{$\begin{array}{l}\text { After } 72 \mathrm{~h} \text { of } \\
\text { application }\end{array}$} \\
\hline & & I & $\mathbf{R}$ & $\mathbf{E}$ & I & $\mathbf{R}$ & $\mathbf{E}$ & I & $\mathbf{R}$ & $\mathbf{E}$ & I & $\mathbf{R}$ & $\mathbf{E}$ \\
\hline \multirow[t]{3}{*}{ AP } & Female-I & $\mathrm{x}$ & $\mathrm{x}$ & $\mathrm{x}$ & $\mathrm{x}$ & $\mathrm{x}$ & $\mathrm{x}$ & $\mathrm{x}$ & $\mathrm{x}$ & $\mathrm{x}$ & $\mathrm{x}$ & $\mathrm{x}$ & $\mathrm{x}$ \\
\hline & Female-II & $\mathrm{x}$ & $\mathrm{x}$ & $\mathrm{x}$ & $\mathrm{x}$ & $\mathrm{x}$ & $\mathrm{x}$ & $\mathrm{x}$ & $\mathrm{x}$ & $\mathrm{x}$ & $\mathrm{x}$ & $\mathrm{x}$ & $\mathrm{x}$ \\
\hline & Female-III & $\mathrm{x}$ & $\mathrm{x}$ & $\mathrm{x}$ & $\mathrm{x}$ & $\mathrm{x}$ & $\mathrm{x}$ & $\mathrm{x}$ & $\mathrm{x}$ & $\mathrm{x}$ & $\mathrm{x}$ & $\mathrm{x}$ & $\mathrm{x}$ \\
\hline
\end{tabular}

I-Skin irritation, R-Redness, E-Erythema, AP-Andrographis paniculata

Table 3: Stability studies of androgaphis paniculata derma sticks

\begin{tabular}{|c|c|c|c|}
\hline Storage temperature & Time of analysis (d) & Physical appearance & pH \\
\hline \multirow{12}{*}{ Atroom temperature $27 \pm 2{ }^{\circ} \mathrm{C}$} & 15 & No change & 7.1 \\
\hline & 30 & No change & 7.0 \\
\hline & 45 & No change & 7.0 \\
\hline & 60 & No change & 7.1 \\
\hline & 75 & No change & 7.0 \\
\hline & 90 & No change & 7.0 \\
\hline & 105 & No change & 7.1 \\
\hline & 120 & No change & 7.0 \\
\hline & 135 & No change & 7.0 \\
\hline & 150 & No change & 7.1 \\
\hline & 165 & No change & 7.0 \\
\hline & 180 & No change & 6.9 \\
\hline
\end{tabular}

Each reading is a mean of three determinations 


\section{RESULTS AND DISCUSSION}

Stearyl alcohol and Cetyl alcohol as stiffening agent while petrolatum used as emollient, propylene glycol and sodium lauryl sulphate were used as humectants and emulsifying agent respectively. A total of six formulations were designed. As the material was uniformly filled in a mould with uniform Medicated sticks of Androgaphis Paniculata were prepared by heating and congealing method. The sticks obtained were of uniform length, thickness and weight respectively. Antimicrobial studies revealed that the drug in formulation shows equal zone of inhibition like a pure drug. The preclinical studies in animals and healthy human volunteer revealed that the prepared formulations will be safe to use for topical applications (fig. 2, 3 and 4).

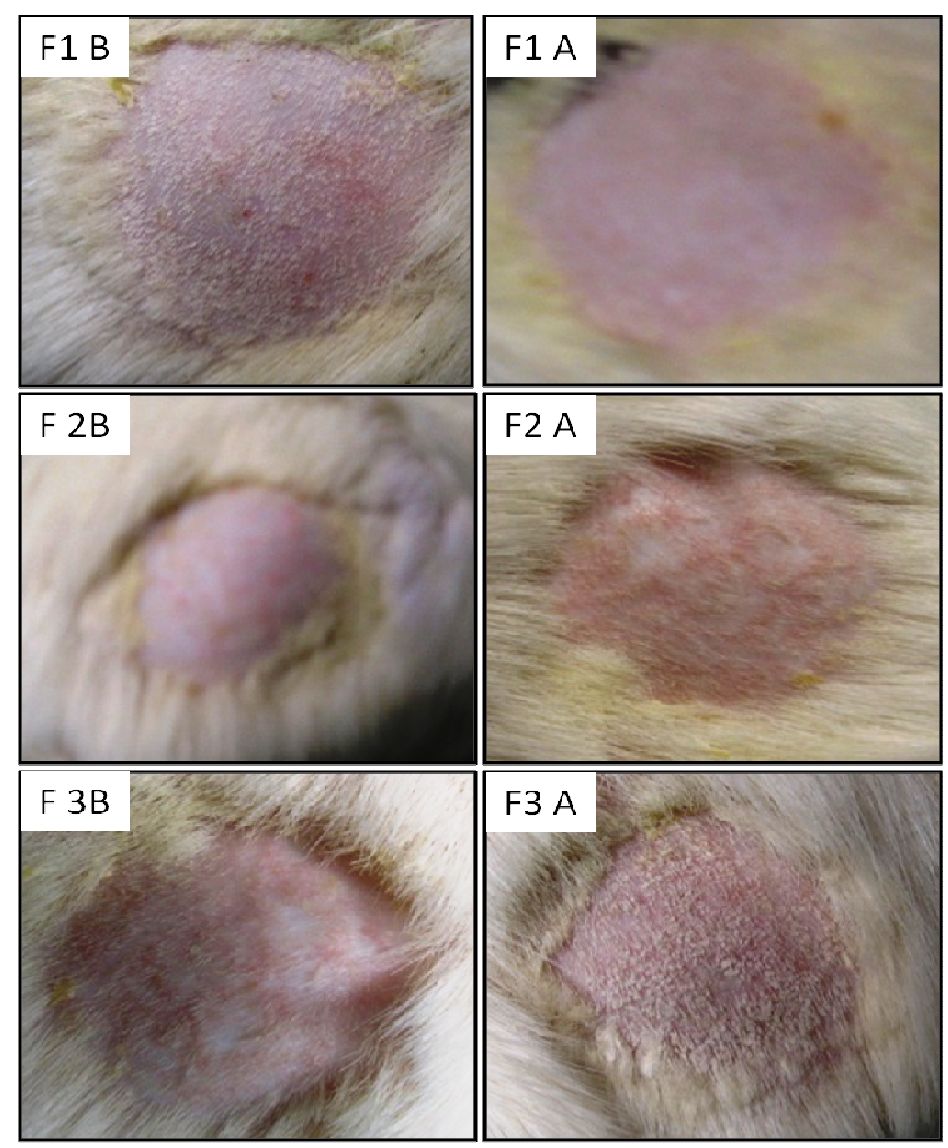

Fig. 2: Primary skin irritation test of one of the group of rabbits

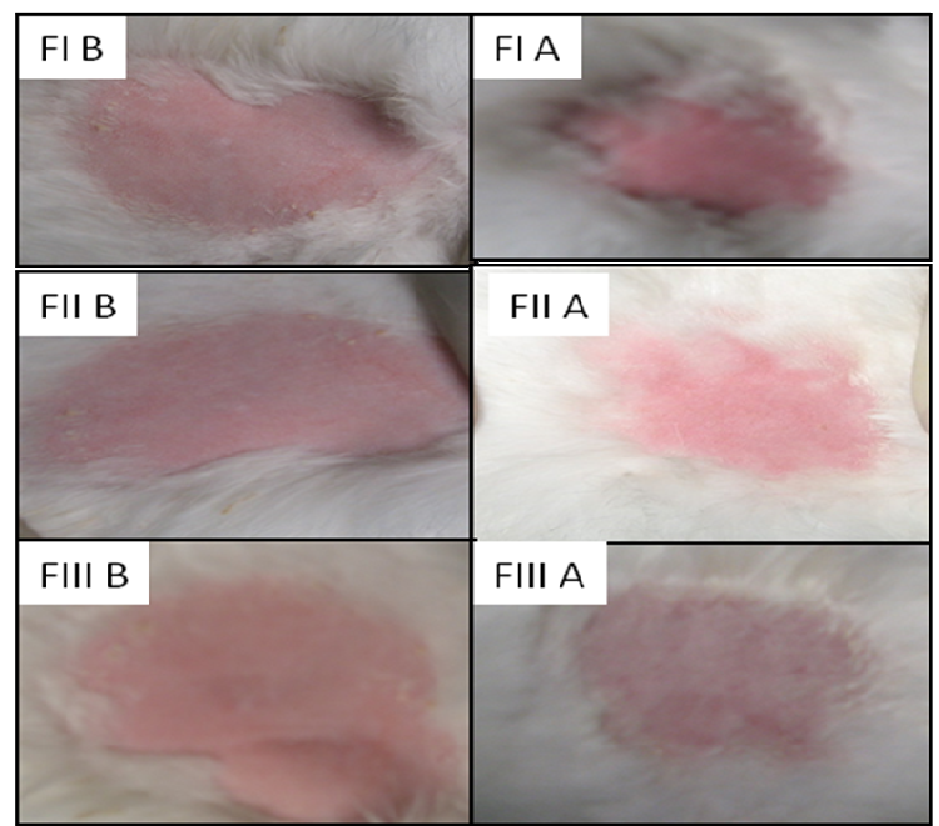

Fig. 3: Primary skin irritation test of one of the group of guinea pigs 

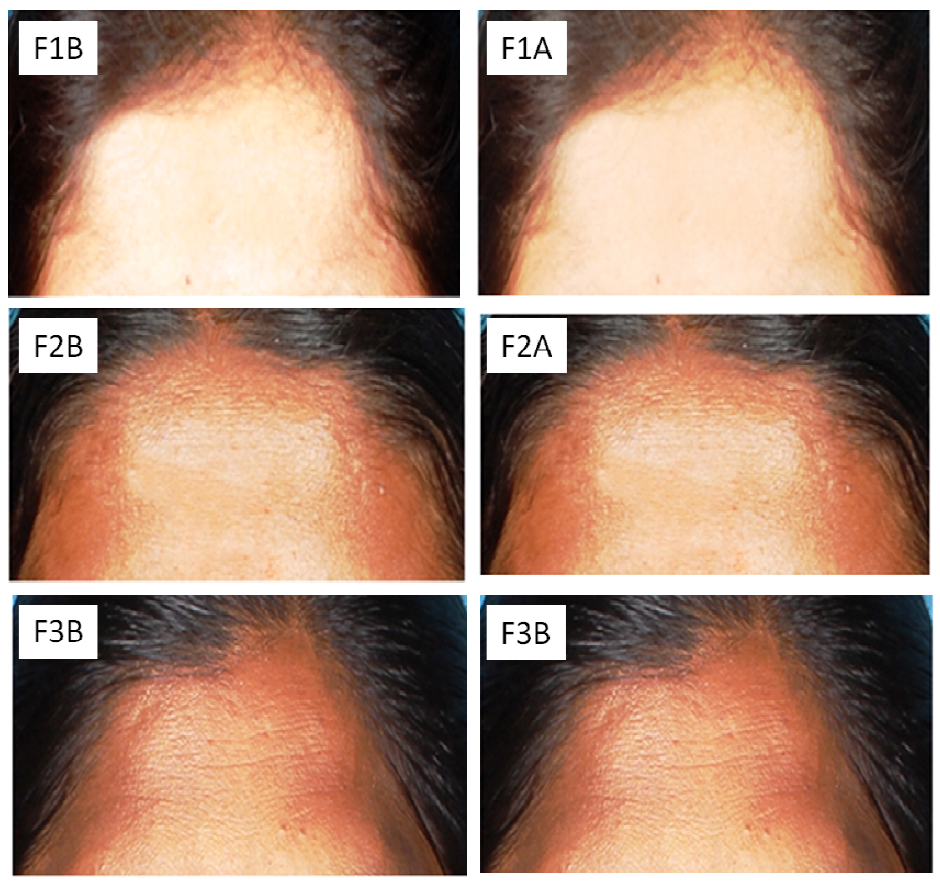

Fig. 4: Primary skin irritation test of healthy human volunteers

\section{CONCLUSION}

The present work is a unique piece of contribution to the drug industry. The results will be useful to industry RandD for further investigations. The continuation of these work clinical studies is in progress.

\section{ACKNOWLEDGEMENT}

We are very much thankful to M/S Euro drug laboratories for the encouragement during the study period.

\section{AUTHORS CONTRIBUTIONS}

All the author have contributed equally.

\section{CONFLICT OF INTERESTS}

Declared none

\section{REFERENCES}

1. Allsworth JE, Peipert JF. Prevalences of bacterial vaginosis. National Health Nutrition Examination Survey Data Obstetgynecol 2007:20:114.

2. Eduard G, FriedrichJr MD. Vaginitis. Am J Obstet Gynaecol 1985:152:247-51.

3. Phee SJ, Papadakis MA. Current Medical Diagnosis and Treatment Lange; 2006:45:731-3.
4. Fuchs P, Schopflin G. Medicated sticks, United States patent Berlin; 1974.

5. Fuchs P, Schopflin G. Medicated Sticks, United States Patent 3,211,618,931: Berlin; 1974

6. Indian pharmacopoeia. Vol. II. $4^{\text {th }}$ ed. New Delhi: The control of publications; 1996. p. 673.

7. British Pharmacopoeia. Vol. II. Her Majesty's stationery office for the department of health; $3^{\text {rd }}$ ed. London; 2008. p. 1920-22.

8. United States Pharmacopoeia. Vol. III. Port city press: Asian ed. US; 2007. p. 3154-55.

9. Sahgal G, Sreeramanan S. Screening selected medicinal plants for antibacterial activity against methicillin-resistant Staphylococcus aureus (MRSA). Adv Nat Appl Sci 2009;3:330-8.

10. US Mishra, A Mishra. Antibacterial activity of ethanol extract of andrographispaniculata. Indian J Pharm Sci 2009;71:436-8.

11. Aniley W, Paul WJ. Handbook of pharmaceutical excipients: profile of stearyl alcohol. The Pharmaceutical Press: London; 1994. p. 498.

12. Aniley W, Paul WJ. Handbook of pharmaceutical excipients: profile of cetyl alcohol. The Pharmaceutical Press: London; 1994. p. 99.

13. R Nalubega, JD Kabasa, D Olila, J Kateregga. Evaluation of antibacterial activity of selected ethnomedicinal plants for poultry in Masaka district, Uganda. Res J Pharmacol 2011;5:18-21.

14. Bango R, Jayakar B. Diffusion studies on salicylic acid ointment through rabbit skin. Indian J Hospital Pharm 1997;2:51-2. 